\title{
Article \\ Preparation and Comprehensive Properties of a High-Radiation-Shielding UHPC by Using Magnetite Fine Aggregate
}

\author{
Jianjun Han ${ }^{1}$, Zhuangmin Xi ${ }^{1}$, Rui Yu ${ }^{2} \mathbb{D}$, Junfeng Guan ${ }^{3} \mathbb{D}$, Yajun $\mathrm{Lv}^{3,4, *}$ and Guo Li ${ }^{5, * \mathbb{D}}$ \\ 1 School of Civil Engineering, Henan University of Technology, Zhengzhou 450001, China; \\ hanjianjun@haut.edu.cn (J.H.); 201993291@stu.haut.edu.cn (Z.X.) \\ 2 State Key Laboratory of Silicate Materials for Architectures, Wuhan University of Technology, \\ Wuhan 430070, China; r.yu@whut.edu.cn \\ 3 School of Architecture, North China University of Water Resources and Electric Power, \\ Zhengzhou 450045, China; junfengguan@ncwu.edu.cn \\ 4 Structural Research Institute, China Institute of Water Resources and Hydropower, Beijing 100038, China \\ 5 School of Mechanics and Civil Engineering, China University of Mining and Technology, \\ Xuzhou 221116, China \\ * Correspondence: lvyajun@ncwu.edu.cn (Y.L.); guoli@cumt.edu.cn (G.L.)
}

check for updates

Citation: Han, J.; Xi, Z.; Yu, R.; Guan, J.; Lv, Y.; Li, G. Preparation and Comprehensive Properties of a High-Radiation-Shielding UHPC by Using Magnetite Fine Aggregate. Materials 2022, 15, 978. https:// doi.org/10.3390/ma15030978

Academic Editor: Sérgio Manuel Rodrigues Lopes

Received: 29 November 2021

Accepted: 18 January 2022

Published: 27 January 2022

Publisher's Note: MDPI stays neutral with regard to jurisdictional claims in published maps and institutional affiliations.

Copyright: (C) 2022 by the authors. Licensee MDPI, Basel, Switzerland. This article is an open access article distributed under the terms and conditions of the Creative Commons Attribution (CC BY) license (https:// creativecommons.org/licenses/by/ $4.0 /)$.
Abstract: Nuclear technology benefits humans, but it also produces nuclear radiation that harms human health and the environment. Based on the modified Andreasen and Andersen particle packing model for achieving a densely compacted cementitious matrix, a new magnetite ultra-highperformance concrete (MUHPC) was designed using magnetite fine aggregate as a substitute for river sands with $0 \%, 20 \%, 40 \%, 60 \%, 80 \%$, and $100 \%$ replacement ratios. The comprehensive properties of the developed MUHPC were tested and evaluated. These properties were fluidity, static and dynamic compressive strengths, high-temperature performance, antiradiation behaviors, hydration products, and micropore structures. Experimental results indicate that the developed MUHPC has high work performance and static and dynamic mechanical properties. The gamma ray shielding performance of MUHPC substantially improves with increased magnetite fine aggregate. Corresponding with $100 \%$ magnetite fine aggregate substitution, the linear attenuation coefficient of MUHPC is enhanced by $56.8 \%$ compared with that of ordinary concrete. Magnetite addition does not change the type of cement hydration products but improves the micropore structures of MUHPC and effectively reduces its total porosity and average pore diameter, thereby contributing to its mechanical and radiation shielding properties. The compressive strength and linear attenuation coefficient of the MUHPC can reach $150 \mathrm{MPa}$ and $0.2 \mathrm{~cm}^{-1}$, respectively. In addition, the MUHPC also exhibits superior mechanical and radiation shielding performance at elevated temperatures $\left(<400{ }^{\circ} \mathrm{C}\right)$. Finally, high strength and antiradiation performance support the use of MUHPC in radiation protection materials in the future.

Keywords: ultra-high-performance concrete; magnetite fine aggregate; fluidity; compressive strength; radiation shielding performance

\section{Introduction}

Different radiation sources and instruments are extensively used in various medical and research centers, petrochemical and refining industries, nuclear power plants, agriculture, and other fields [1-4]. Nuclear shielding technology is also eliciting public attention. Generally, gamma and neutron rays are the most destructive radiation types released by nuclear explosion or radioactive waste [5-7]. The danger of these radiation types primarily originates from their high penetration and ionization energy, which can destroy normal human cells and lead to gene mutation. Long-term exposure to nuclear radiation causes immune decline, cancer, and even immediate death, among other problems, in humans [8-12]. 
Thus, the effective radiation shielding of nuclear facilities is very important. However, satisfactory radiation-proof building materials for high-radiation-shielding purposes remain lacking [13].

The interaction modes of a ray and matter include a photoelectric effect, Compton scattering, and an electron pair effect [2,6]. The principle of radiation shielding can be simply understood as when a ray passes through an antiradiation material, part of the energy of the incident photon is absorbed by the antiradiation material, the original photon is scattered, and its motion direction and energy change, thus the radiation energy is attenuated. Elements with high atomic number and high-density materials reportedly exert good radiation attenuation effects $[2,14]$. Common gamma ray shielding materials include iron, tungsten, lead, concrete, metal alloys, and heavy aggregates such as magnetite, hematite, and barite [15-21]. Among them, lead has been the most extensively used since the discovery of gamma rays. Lead has a high atomic number and density, as well as excellent photoelectric effect probability. Most hospitals and laboratories currently use lead plate or lead sheet as the main radiation barrier. However, some characteristics of lead, such as toxicity, low mechanical properties, and poor stability, are undesirable. Meanwhile, concrete has become the most widely used radiation shielding material because of its abundant raw materials, low cost, good durability, and simple production [17,22-26]. Ouda and AbdelGawwad [27] compared the physical and mechanical properties and radiation attenuation power against gamma rays of heavyweight magnetite concrete with those of heavyweight barite and goethite concretes. They found that the comprehensive properties of magnetite concrete are higher than those of barite and goethite concretes. Horszczaruk et al. [18] found that the application of heavyweight magnetite aggregates can reduce the negative impacts of high temperature on the mechanical characteristics of radiation shielding concrete. Çullu and Bakırhan [28] observed that the strength grade of concrete affects the coefficient of radiation absorption in heavyweight lead-zinc concretes. Saidani et al. [29] and González-Ortega et al. [30] reported that the application of barite powder and barite aggregates in heavyweight concrete for the purpose of radiation shielding in nuclear facilities and hospitals results in reduced concrete mechanical properties. Generally, currently prepared radiation-proof concretes have good radiation-proof performance but the same problem of low strength. With the development of nuclear power technology, the power and designed service life of nuclear reactors have increased. For example, the designed life for the Hualong- 1 reactor in China is 60 years [31], corresponding to higher requirements of the radiation shielding of nuclear facilities. Therefore, preparing radiation-proof concrete with higher strength and durability is of great practical significance.

Ultra-high-performance concrete (UHPC) is a new type of cement-based composite material with ultra-high strength, good toughness, and durability, indicating broad application prospects [32-34]. The excellent performance of UHPC is, in part, due to its highly compact packing design. Good gradation makes it dense and low porosity makes it able to effectively resist the attack of harmful media, which is an important aspect in maintaining its high durability [35,36]. Due to the high cement content $\left(900-1100 \mathrm{~kg} / \mathrm{m}^{3}\right)$ in UHPC, the water binder ratios of UHPC are generally in the range of 0.18-0.3 [37-39]. Low water/binder ratios lead to the existence of numerous unhydrated cement particles inside, conferring it with a certain self-repairing ability. Thus, it can meet the high-performance requirements of engineering structures in various severe environments [40-44]. In recent years, many researchers [32,45-47] have reported the development of UHPC and evaluated its mechanical and durability performance. However, studies on radiation-proof UHPC are few and remain in the initial stages [48].

The present study aimed to design a novel UHPC with high radiation resistance to meet the current challenges for nuclear facilities. Different proportions of magnetite fine aggregate $(0 \%, 20 \%, 40 \%, 60 \%, 80 \%$, and $100 \%)$ were used to replace natural river sands and prepare radiation-proof UHPC. The work performance, mechanical properties before and after high-temperature treatments, gamma ray shielding performance, micromorphology, and micropore structure of the magnetite UHPC (MUHPC) were tested and analyzed. The 
developed MUHPC was found to exhibit superior comprehensive mechanical and radiation shielding performance.

\section{Materials and Methods}

\subsection{Raw Materials}

The binder materials of cement, fly ash, and silica fume were P.II 52.5 Portland cement (Yong'an Cement Co., Ltd., Henan, China), grade I fly ash (Rongchangsheng Environmental Protection Material Factory, Henan, China), and microsilica fume (Yumin Micro Silica Fume Co., Ltd., Henan, China) in this study. According to an X-ray fluorescence analysis (XRF) (Thermo Fisher Scientific, Waltham, MA, USA) test, the chemical compositions of cement, silica fume, and fly ash are shown in Table 1. The fine aggregates used were natural river sands (Baoting Engineering Construction Co., Ltd., Hebei, China) with a density of $2550 \mathrm{~kg} / \mathrm{m}^{3}$ and magnetite fine aggregate (Jiashun Water Purification Material Factory, Henan, China) with a density of $5100 \mathrm{~kg} / \mathrm{m}^{3}$. The chemical compositions of the magnetite fine aggregate are presented in Table 2, and the main chemical compositions were $\mathrm{Fe}_{2} \mathrm{O}_{3}$ and $\mathrm{TiO}_{2}$. The water-reducing agent used was a kind of polycarboxylate superplasticizer (Sobute New Materials Co., Ltd., Jiangsu, China) with a water-reducing ratio of $30 \%$ and solid content of $30 \%$. The steel fibers were copper-plated microsteel fibers that were $13 \mathrm{~mm}$ long and $0.22 \mathrm{~mm}$ in diameter (Daitian Engineering Materials Co., Ltd., Shandong, China). The mixing water was ordinary tap water.

Table 1. Chemical composition of the used cement, silica fume, and fly ash (\%).

\begin{tabular}{ccccccccccc}
\hline Item & $\mathbf{N a}_{\mathbf{2}} \mathbf{O}$ & $\mathbf{M g O}$ & $\mathbf{A l}_{\mathbf{2}} \mathbf{O}_{\mathbf{3}}$ & $\mathbf{S i O}_{\mathbf{2}}$ & $\mathbf{P}_{\mathbf{2}} \mathbf{O}_{\mathbf{5}}$ & $\mathbf{S O}_{\mathbf{3}}$ & $\mathbf{K}_{\mathbf{2}} \mathbf{O}$ & $\mathrm{CaO}$ & $\mathbf{F e}_{\mathbf{2}} \mathbf{O}_{\mathbf{3}}$ & $\mathbf{L O I}$ \\
\hline Cement & 0.07 & 1.73 & 4.24 & 18.25 & 0.08 & 3.25 & 0.87 & 65.03 & 3.38 & 3.10 \\
Silica Fume & 0.25 & 0.37 & 0.22 & 94.85 & 0.13 & 0.79 & 0.64 & 0.32 & 0.18 & 2.25 \\
Fly Ash & 0.28 & 0.36 & 38.85 & 46.82 & 0.07 & 0.62 & 0.84 & 7.8 & 2.85 & 1.51 \\
\hline
\end{tabular}

Table 2. Chemical composition of magnetite fine aggregate.

\begin{tabular}{cccccccc}
\hline Compositions & $\mathrm{MgO}$ & $\mathrm{Al}_{\mathbf{2}} \mathrm{O}_{\mathbf{3}}$ & $\mathrm{SiO}_{2}$ & $\mathrm{CaO}$ & $\mathrm{Fe}_{2} \mathrm{O}_{3}$ & $\mathrm{TiO}_{2}$ & $\mathrm{LOI}$ \\
\hline Content (\%) & 1.99 & 5.52 & 13.8 & 4.15 & 49.31 & 24 & 1.23 \\
\hline
\end{tabular}

Photographs of magnetite fine aggregate and river sands are shown in Figure 1. Magnetite fine aggregate is black and fine with irregular particles having a rough surface (Figure 2). Its fineness is slightly lower than that of river sands.

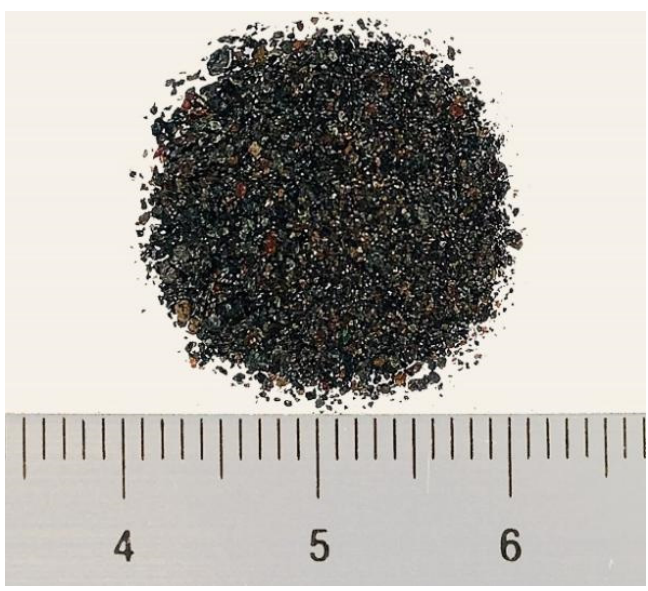

(a)

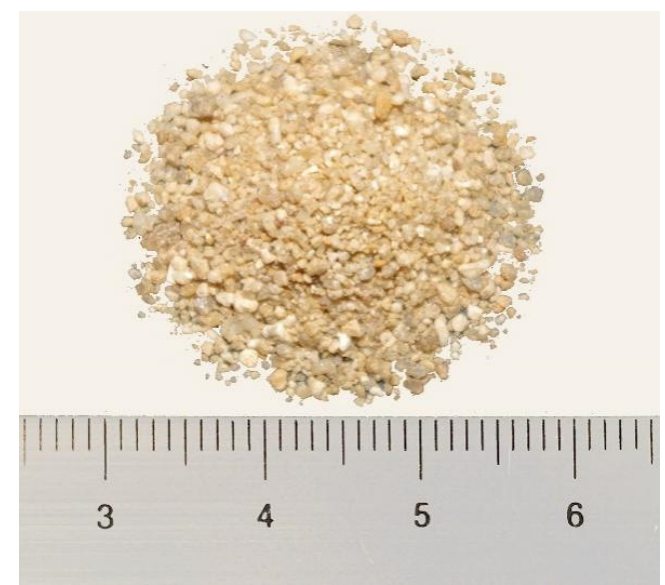

(b)

Figure 1. Photograph of fine aggregates used. (a) Magnetite fine aggregate. (b) River sands. 


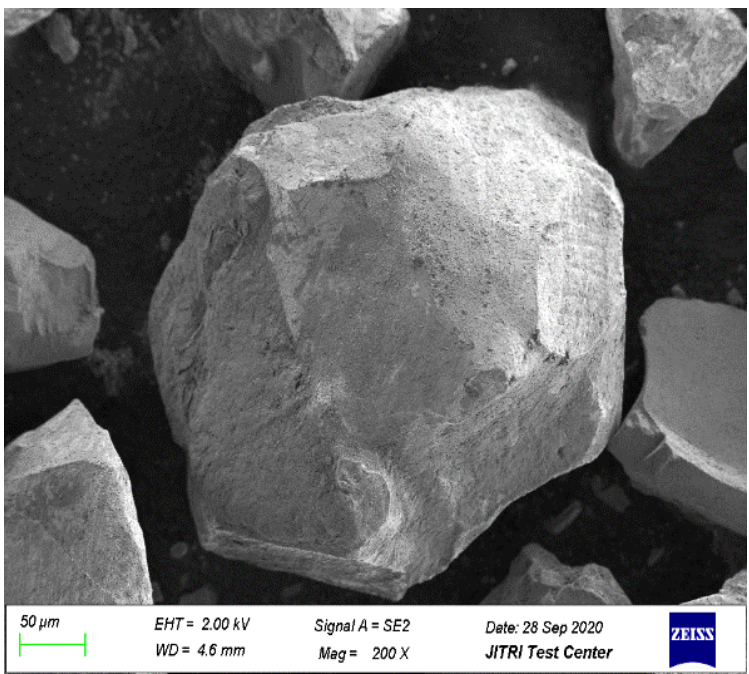

Figure 2. SEM image of magnetite particle.

\subsection{Mixture Design of MUHPC}

The compressive packing model is the key to developing UHPC [44]. In this study, the modified Andreasen and Andersen (A\&A) model (Equation (1)) [49] was used to design a dense particle packing skeleton aimed at improving the overall performance of MUHPC. By adjusting the proportions of each individual material with MATLAB software (Matlab2016a Natick, MA, USA), an optimum fit between the composed mixture and the target curve can be reached. Based on constant volume substitution, different replacement levels of $0 \%$, $20 \%, 40 \%, 60 \%, 80 \%$, and $100 \%$ magnetite fine aggregate were used to replace river sands, and then the mixture proportions of MUHPC were obtained, as listed in Table 3.

$$
P(D)=\frac{D^{q}-\left(D_{\min }\right)^{q}}{\left(D_{\max }\right)^{q}-\left(D_{\min }\right)^{q}}
$$

where $D$ is the particle size $(\mathrm{mm}), P(D)$ is a fraction of solids smaller than size $D, D_{\max }$ is the maximum size of the utilized particle $(\mathrm{mm}), D_{\min }$ is the minimum size of the utilized particle $(\mathrm{mm})$, and $q$ is the distribution modulus. $q$ was fixed at 0.23 in this study, in accordance with the literature [49].

Table 3. Composition of MUHPC used in this study $\left(\mathrm{kg} / \mathrm{m}^{3}\right)$.

\begin{tabular}{ccccccccccc}
\hline \multirow{2}{*}{ Item } & \multirow{2}{*}{ Silica Fume } & Cement & Fly Ash & \multicolumn{2}{c}{ River Sand/mm } & \multicolumn{2}{c}{ Magnetite/mm } & \multicolumn{2}{c}{ Water } & Steel Fiber \\
& & & & $\mathbf{0 - 0}$ & $\mathbf{0 . 6 - 1 . 1 8}$ & $\mathbf{0 - 0 . 6}$ & $\mathbf{0 . 6 - 1 . 1 8}$ & Water & Reducer & Red \\
\hline R0 & 101 & 803 & 181 & 717 & 263 & 0 & 0 & 206 & 30 & 156 \\
R20 & 101 & 803 & 181 & 574 & 210 & 287 & 105 & 206 & 30 & 156 \\
R40 & 101 & 803 & 181 & 430 & 158 & 574 & 210 & 206 & 30 & 156 \\
R60 & 101 & 803 & 181 & 287 & 105 & 860 & 316 & 206 & 30 & 156 \\
R80 & 101 & 803 & 181 & 143 & 53 & 1148 & 421 & 206 & 30 & 156 \\
R100 & 101 & 803 & 181 & 0 & 0 & 1434 & 526 & 206 & 30 & 156 \\
\hline
\end{tabular}

\subsection{Specimen Fabrication}

To obtain a well-mixed concrete composite, a strict mixing procedure was followed. Firstly, the binder materials and fine aggregates were placed in a mortar mixer (Shengxing Instrument Equipment Co., Ltd., Hebei, China) and mixed for $2 \mathrm{~min}$ at a low speed $(140 \pm 5 \mathrm{r} / \mathrm{min})$. Secondly, water and superplasticizer were added under continued mixing at a low speed for $3 \mathrm{~min}$. Lastly, the steel fibers were slowly added under continued mixing at a high speed $(285 \pm 5 \mathrm{r} / \mathrm{min})$ for $2 \mathrm{~min}$. The prepared fresh MUHPC was casted into 
molds with different sizes. The specimens were demolded $24 \mathrm{~h}$ after casting and placed in an artificial climate room for curing $\left(T=20 \pm 2{ }^{\circ} \mathrm{C}\right.$ and $\left.R H \geq 95 \%\right)$ until the age of 28 days.

\subsection{Experimental Methods}

\subsubsection{Fluidity Test}

According to BS EN1015-3 [50], the fluidity of fresh MUHPC was tested using a mold of a truncated cone (Fangyuan Construction Instrument Factory, Hebei, China) with a top diameter of $70 \mathrm{~mm}$, bottom diameter of $100 \mathrm{~mm}$, and height of $60 \mathrm{~mm}$. Firstly, the mold was placed on a jump table (Fangyuan Construction Instrument Factory, Hebei, China) in advance and the fresh MUHPC was placed in the mold in two layers. Then, the jump table was started once the mold was vertically lifted. After 25 jumps, the collapsed mortar's two diameters perpendicular to each other were measured and averaged as the fluidity of the fresh MUHPC.

\subsubsection{Static Compressive Strength Test}

According to BS EN-196-1 [51], the static compressive strength of MUHPC was tested using an electrohydraulic servo testing machine (Changchun New Testing Machine Co., Ltd., Jilin, China) with a loading rate of $2.4 \mathrm{kN} / \mathrm{s}$. Specimens for compressive strength were blocks with a size of $40 \times 40 \times 160 \mathrm{~mm}^{3}$. At least three replica specimens were utilized for each batch, and the average value was taken as the representative value.

\subsubsection{Dynamic Compressive Strength Test}

Partial block specimens of R0 and R100 at the age of 28 days were cut into a size of $12 \times 12 \times 45 \mathrm{~mm}^{3}$ and subjected to dynamic compressive strength tests. The dynamic compressive strength of MUHPC specimens were determined using an electrohydraulic servo high-speed testing system (Instron Corporation, Boston, MA, USA), whose impact speed can reach $20 \mathrm{~m} / \mathrm{s}$ and maximum dynamic load can reach $100 \mathrm{kN}$. The sampling frequency of the data acquisition system was $65 \mathrm{kHz}$, and the impact velocities were set at $0.5,1,3$, and $5 \mathrm{~m} / \mathrm{s}$, respectively.

\subsubsection{High-Temperature Treatment}

During the operation of a nuclear power plant, nuclear reactor concrete may suffer from high temperatures, so it is necessary to study its mechanical properties at elevated temperatures. MUHPC specimens similar to those used for the static compressive strength experiment were prepared for heat treatments. To avoid high-temperature burst as much as possible, MUHPC specimens were dried in an oven at $105^{\circ} \mathrm{C}$ for $24 \mathrm{~h}$ in advance and then heated in a muffle furnace (Keruida Electric Furnace Co., Ltd., Shandong, China) according to the RILEM criterion [48]. Generally, the specimens were heated at a speed of $3{ }^{\circ} \mathrm{C} / \mathrm{min}$ until a target temperature, and the target temperature was kept constant for $1 \mathrm{~h}$. The specimens were cooled down to room temperature at a rate of $3{ }^{\circ} \mathrm{C} / \mathrm{min}$, and the target temperatures were set at $200{ }^{\circ} \mathrm{C}, 400{ }^{\circ} \mathrm{C}$, and $600{ }^{\circ} \mathrm{C}$, respectively. After the high-temperature exposure, the specimens were tested for compressive strength and gamma ray shielding performance.

\subsubsection{Gamma Ray Shielding Experiment}

MUHPC specimens for the radiation shielding performance test were prepared as blocks with a section size of $150 \times 150 \mathrm{~mm}^{2}$ and different thicknesses. The shielding performance of MUHPC was tested with a gamma ray spectrometer (Cs-137 as radiation source, energy of $662 \mathrm{keV}$, Jingcheng Instrument Co., Ltd., Shandong, China) and evaluated by the linear attenuation coefficient $\mu$, which represents the probability that the gamma ray will be absorbed when it passes through a material per unit distance. The definition of $\mu$ is shown in Equation (2) [48]. A higher $\mu$ means stronger shielding performance of a material.

$$
\mu=\frac{1}{x} \ln \left(\frac{I_{0}}{I}\right)
$$


where $I_{0}$ is the initial radiation intensity $(\mathrm{keV}), I$ is the intensity after radiation transmission $(\mathrm{keV})$, and $x$ is the thickness of a testing material $(\mathrm{cm})$.

\subsubsection{Hydration Products, Micromorphology, and Pore Structures}

X-ray diffraction (XRD) analysis was conducted using an X-ray diffractometer (Bruker D8, Karlsruhe, Germany) on powder samples extracted from different MUHPC specimens aged for 28 days. The micromorphologies of MUHPC particle samples were observed under a Hitachi S4800 field-emission scanning electron microscopy (SEM) system (Tokyo, Japan). The samples were soaked in ethanol for $24 \mathrm{~h}$ and dried in a vacuum oven (DSA Instruments Co., Ltd., Beijing, China) to stop the hydration in advance. The pore structures of partial MUHPC particle samples were analyzed using a mercury intrusion porosimeter (MIP; AutoPore IV 9510, Micro-meritics Instrument Corporation, Norcross, GA, USA) with a maximum mercury pressure of $413 \mathrm{MPa}$ and a contact angle of $140^{\circ}$.

\section{Results}

\subsection{Working Performance}

The influences of magnetite powder content on MUHPC fluidity are shown in Figure 3. MUHPC's fluidity obviously decreased with increased magnetite powder content, and the relationship between them was approximately linear. Corresponding with $100 \%$ replacement ratio, the fluidity of MUHPC decreased to $233 \mathrm{~mm}$, which was an approximately $16 \%$ reduction compared with that of the control ( $0 \%$ replacement ratio). This finding may be ascribed to the fact that river sand particles are usually round and smooth, whereas magnetite particles are irregular and have a surface rough (Figure 2). Thus, the substitution of the magnetite fine aggregate increases the friction among particles in a MUHPC mixture and causes a decrease in fluidity. Usually, when a UHPC's fluidity is higher than $180 \mathrm{~mm}$, it can be considered as a high-mobility concrete [32,36]. Notably, the fluidity values of the MUHPC mixtures were only slightly reduced, and even MUHPC with 100\% replacement ratio can retain its high fluidity, which is important for applications in practical engineering construction.

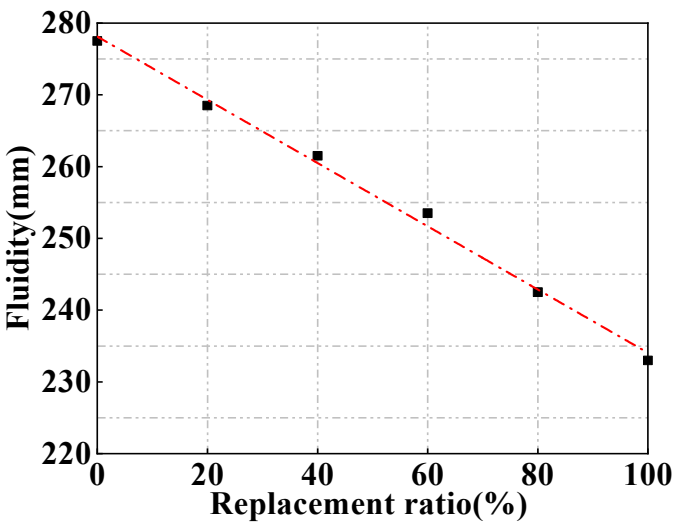

Figure 3. Fluidity of fresh MUHPC with different magnetite contents.

\subsection{Static Compressive Strength}

Generally, high-hardness aggregates benefit the compressive strength of UHPC [42,43]. The Mohs hardness of magnetite fine aggregate (5.5-6.5) was lower than that of river sands (6.5-7), which is unfavorable to MUHPC's compressive strength. Figure 4 presents the compressive strengths of MUHPC specimens. The compressive strength developments of all MUHPC specimens with curing ages were similar, i.e., a longer curing age corresponded with higher concrete compressive strength. Meanwhile, as expected, the compressive strengths of MUHPC tended to drop a little after the substitution of magnetite fine aggregate. Compared with that of the control ( $0 \%$ replacement ratio), the 28 -day compressive strengths of MUHPC specimens with magnetite replacement ratios of $20 \%, 40 \%, 60 \%, 80 \%$, and $100 \%$ 
decreased by $2.56 \%, 4.49 \%, 3.2 \%, 3.2 \%$, and $4.49 \%$, respectively. The average reduction was $3.6 \%$, indicating that the incorporation of magnetite fine aggregate did not exert obvious negative effects on MUHPC's compressive strength. In this paper, the minimum 28-day compressive strength of the MUHPC specimens was near $150 \mathrm{MPa}$, which can satisfy the compressive strength usually stipulated for UHPC [52].

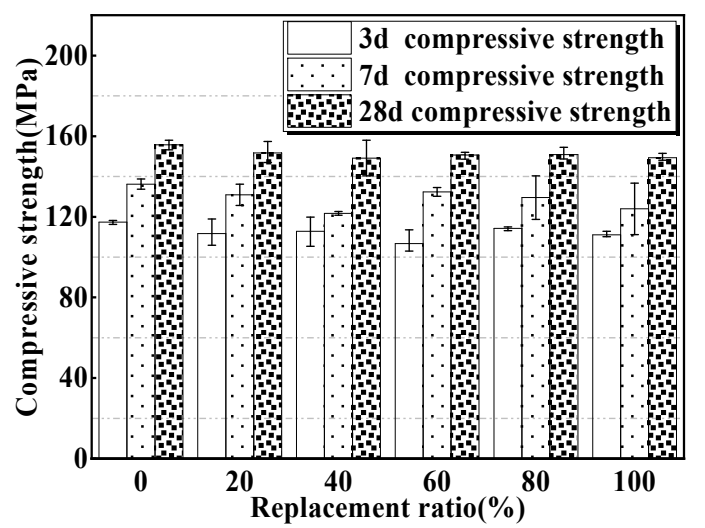

Figure 4. Compressive strengths of MUHPC with different magnetite contents.

\subsection{Dynamic Compressive Strength}

The dynamic compressive strengths of MUHPC caused by impact loads were calculated using the ratio of the maximum impact forces to the contact areas [53]. Generally, the dynamic compressive strength of concrete is markedly higher than its static compressive strength $[53,54]$. Figure 5 shows the time history of stress response of R0 and R100 specimens under different impact velocities.

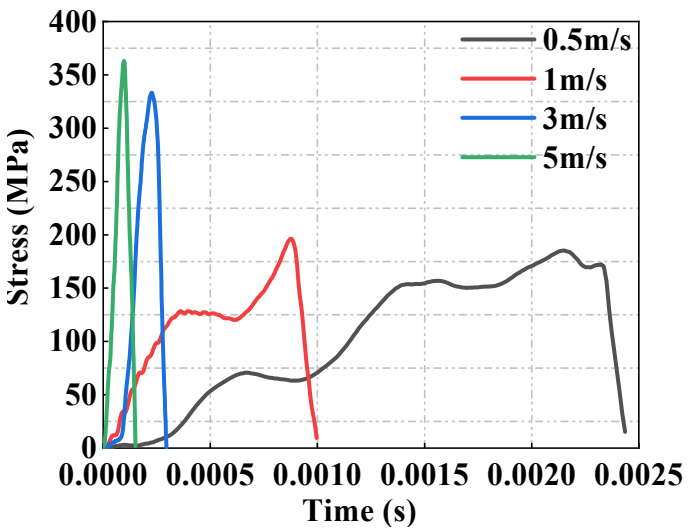

(a)

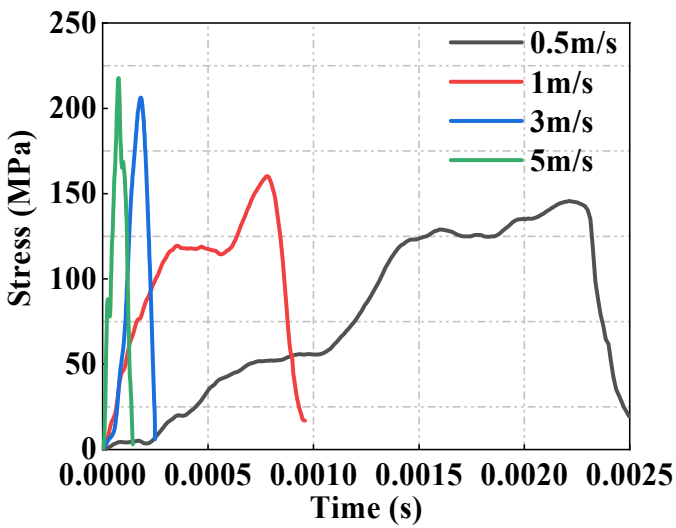

(b)

Figure 5. Stress response of partial MUHPC specimens under different impact velocities. (a) R0. (b) R100.

The stress developments of R0 and R100 under different impact loading velocities were very similar, and high-impact velocity usually corresponded with high dynamic compressive strength. For example, corresponding with the impact velocities of $0.5,1,3$, and $5 \mathrm{~m} / \mathrm{s}$, the dynamic strengths of R100 were 149,160, 206, and $218 \mathrm{MPa}$, respectively. Compared with that of the static compressive strength of R0 and R100, the dynamic strengths were enhanced by $17.6-126 \%$ and $0-46.3 \%$, respectively. Notably, the dynamic compressive strengths of R100 were lower than those of R0 under the same impact loads, which may be attributed to the low Mohs hardness of magnetite. However, the dynamic compressive strengths of R100 were near or more than $150 \mathrm{MPa}$, which can provide high impact resistance. 


\subsection{Compressive Strength at Elevated Temperatures}

The compressive strengths of MUHPC specimens after different heat treatments are plotted in Figure 6. The development of the compressive strengths of all MUHPC specimens with the exposure temperature exhibited a similar trend, i.e., the compressive strength initially increased and then decreased with further increased temperature. Specifically, the compressive strengths of MUHPC reached the maximum value at $200{ }^{\circ} \mathrm{C}$ and then declined gradually. For example, the compressive strengths of R0, R20, R40, R60, R80, and R100 specimens after exposure to $200{ }^{\circ} \mathrm{C}$ were $1.28 \%, 4.6 \%, 6.71 \%, 11.26 \%, 13.25 \%$, and $6 \%$ higher than those exposed to room temperature. This phenomenon has also been observed in other studies [48,55-57], which may be ascribed to the activation of unhydrated and inadequately hydrated cementitious materials by high temperature, thereby contributing to the compressive strength of MUHPC through rehydration reaction [44,45].

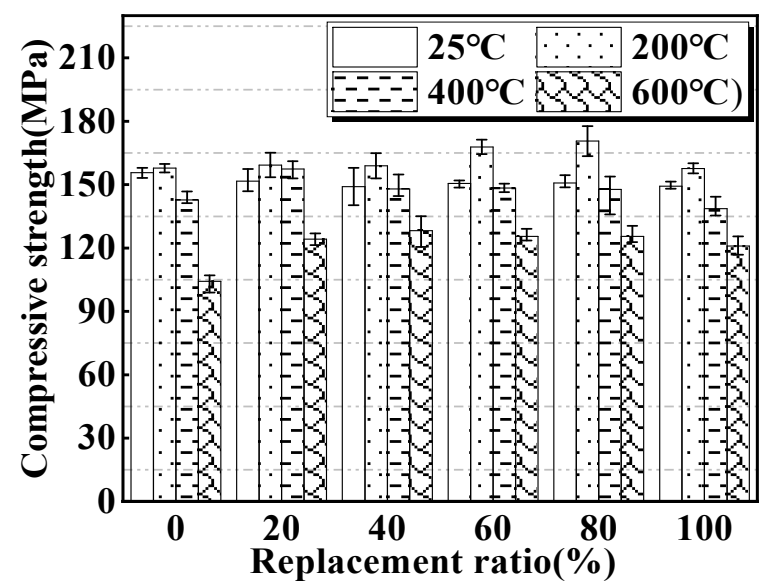

Figure 6. Compressive strengths of MUHPC after different high-temperature exposures.

With increases in temperature to $400{ }^{\circ} \mathrm{C}$ and $600{ }^{\circ} \mathrm{C}$, the compressive strengths of MUHPC began to drop gradually. For example, after exposure to $600^{\circ} \mathrm{C}$, the compressive strengths of R0, R20, R40, R60, R80, and R100 specimens decreased by 33.3\%, 18.4\%, 14.1\%, $16.6 \%, 16.6 \%$, and $18.8 \%$, respectively. Typical images of MUHPC specimens after different high-temperature exposures are shown in Figure 7. The appearances of the specimens after $200^{\circ} \mathrm{C}$ or $400{ }^{\circ} \mathrm{C}$ exposure were almost unchanged, whereas after $600{ }^{\circ} \mathrm{C}$ exposure, the specimens exhibited obvious cracks. The cracking of MUHPC can be explained by the transformation of $\mathrm{Ca}(\mathrm{OH})_{2}$ to $\mathrm{CaO}$ at $400-600{ }^{\circ} \mathrm{C}$, which leads to the expansion of hardened cement paste followed by shrinkage [58]. Calcium hydroxide can be converted into lime and water vapor during heating, and serious damages are inflicted by lime expansion during cooling, which may be the main reason for the decline in concrete strength.

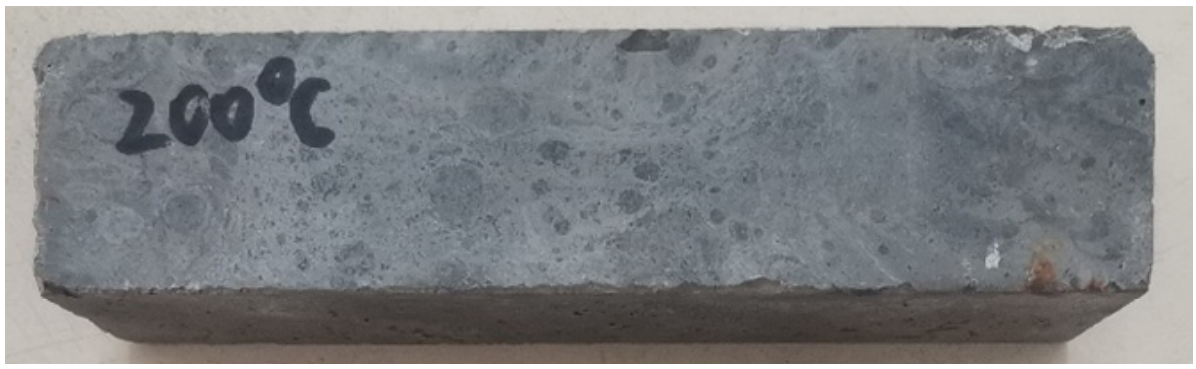

(a)

Figure 7. Cont. 


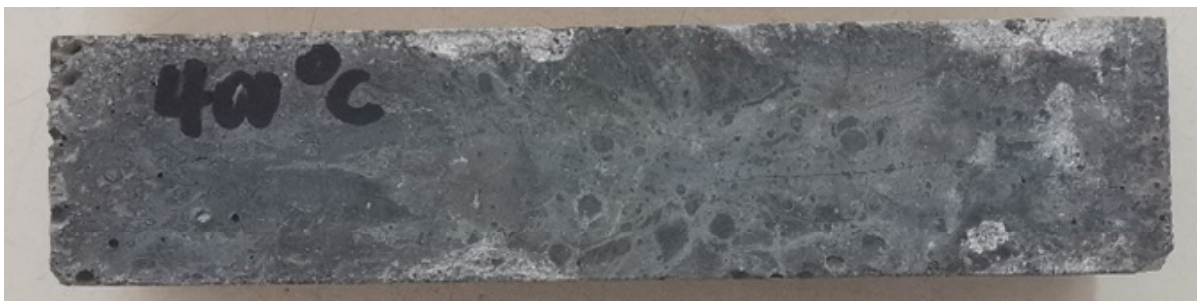

(b)

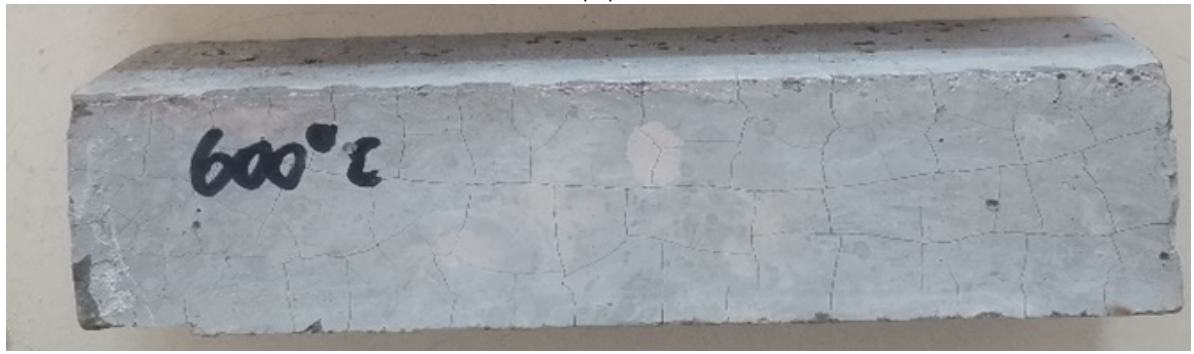

(c)

Figure 7. Typical photographs of R100 specimens with different high-temperature exposures. (a) $200^{\circ} \mathrm{C}$. (b) $400{ }^{\circ} \mathrm{C}$. (c) $600^{\circ} \mathrm{C}$.

Notably, regardless of the exposure temperatures of $200{ }^{\circ} \mathrm{C}, 400{ }^{\circ} \mathrm{C}$, or $600{ }^{\circ} \mathrm{C}$, the compressive strengths of MUHPC were all higher than that of the control ( $\% \%$ replacement ratio) after the incorporation of magnetite fine aggregate. For example, compared with that of the control, the compressive strengths of MUHPC with magnetite replacement ratios of 20\%, $40 \%, 60 \%, 80 \%$, and $100 \%$ increased by $19.2 \%, 23.1 \%, 21.1 \%, 21.1 \%$, and $16.3 \%$, respectively. The average enhancement in compressive strength after adding magnetite fine aggregate was $20.2 \%$, which indicates that MUHPC has very good high-temperature performance.

\subsection{Radiation Shielding Performance at Room Temperature}

Based on the gamma ray shielding results of $\mathrm{R} 0$ and $\mathrm{R} 100$, the data of $\ln \left(I_{0} / I\right)$ and specimens' thickness $x$ were plotted and linearly fitted by the least-square method, and results are shown in Figure 8. According to Equation (2), the slopes of the fitting lines between $\ln \left(I_{0} / I\right)$ and $x$ are the linear attenuation coefficients of R0 and R100.

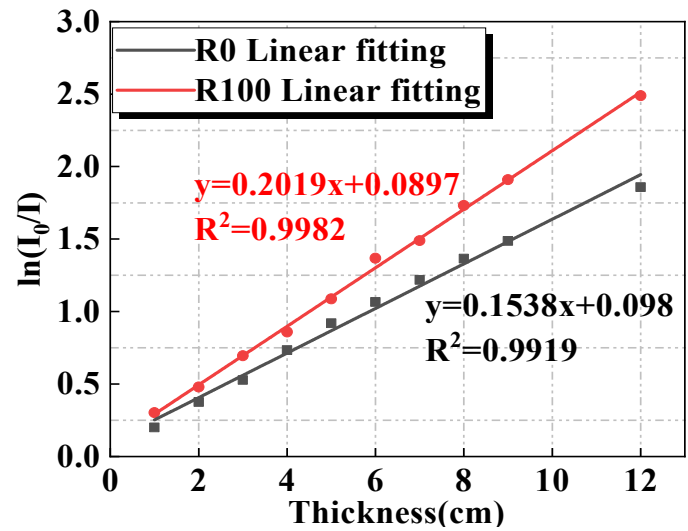

Figure 8. Typical results of $\ln \left(I_{0} / I\right)$ and thicknesses of tested specimens.

Through a similar method, the $\mu$ values of MUHPC with different magnetite replacements were determined and are listed in Table 4 . Obviously, $\mu$ increased with increased magnetite content. Specifically, the $\mu$ values of R0, R20, R40, R60, R80, and R100 were $19.4 \%, 29.4 \%, 31.4 \%, 48.8 \%$, and $56.8 \%$ higher than those of ordinary concrete [14]. Thus, the radiation shielding performance of MUHPC substantially improves with increased magnetite fine aggregate. 
Table 4. Linear attenuation coefficients of MUHPC.

\begin{tabular}{cccccccc}
\hline Item & Ordinary Concrete [14] & R0 & R20 & R40 & R60 & R80 & R100 \\
\hline$\rho\left(\mathrm{g} / \mathrm{cm}^{3}\right)$ & 2.30 & 2.45 & 2.65 & 2.85 & 3.04 & 3.23 & 3.43 \\
$\mu\left(\mathrm{cm}^{-1}\right)$ & 0.1288 & 0.1538 & 0.1667 & 0.1693 & 0.1891 & 0.1917 & 0.2019 \\
\hline
\end{tabular}

Khan et al. [59] and Sikora et al. [60] confirmed that materials with higher density and higher atomic number have higher radiation shielding performance. The strong radiation shielding performance of the developed MUHPC can be attributed to two aspects. On one hand, as shown in Table 4, the densities of MUHPC substantially increased with the substitution of magnetite fine aggregate. Compared with that of ordinary concrete, the density of R100 increased by $49.1 \%$. On the other hand, magnetite fine aggregate has high contents of iron, titanium, and other elements with high atomic numbers (Table 2). When gamma rays enter concrete, their photons collide with the extra nuclear electrons of these elements, thereby weakening the transmission force of gamma rays and improving the radiation shielding performance of MUHPC [61].

\subsection{Radiation Shielding Performance at Elevated Temperatures}

To study the radiation shielding performance of the developed MUHPC at elevated temperatures, the gamma ray shielding performance of R100 was tested after different hightemperature exposures. Considering the obvious cracks in MUHPC specimens exposed to $600{ }^{\circ} \mathrm{C}$ (Figure 7), only exposure temperatures of $200{ }^{\circ} \mathrm{C}$ and $400{ }^{\circ} \mathrm{C}$ were adopted. The corresponding $\mu$ values of R100 after such temperature exposures were 0.1908 and $0.1738 \mathrm{~cm}^{-1}$, which were $5.5 \%$ and $13.18 \%$ lower than that at room temperature, respectively. Obviously, the radiation shielding performance of MUHPC reduced after high-temperature exposure. The reason for the decline in radiation protection performance may be the high-temperature damages to the micropore structures in MUHPC, resulting in increased porosity. However, the $\mu$ values of R100 after $200{ }^{\circ} \mathrm{C}$ and $400{ }^{\circ} \mathrm{C}$ exposures remained higher than that of ordinary concrete [14] by $48.1 \%$ and $34.9 \%$, respectively. This finding means that MUHPC still has good radiation shielding performance, even after high-temperature exposure (below $400{ }^{\circ} \mathrm{C}$ ).

\subsection{Hydration Products}

Figure 9 shows the mineralogical information of the hydrated MUHPC samples. In general, the hydration products remained the same in MUHPC with and without magnetite fine aggregates [62]. Only ettringite and portlandite were detected in the hydration products of all samples. The peak intensities of $\mathrm{C}_{3} \mathrm{~S}$ and $\mathrm{C}_{2} \mathrm{~S}$ were obvious in all mixtures, especially for samples containing magnetite fine aggregate. Conversely, the peak intensity of $\mathrm{Ca}(\mathrm{OH})_{2}$ decreased with increased magnetite fine aggregate, implying less $\mathrm{Ca}(\mathrm{OH})_{2}$ was generated in MUHPC. This phenomenon is probably due to the inhibited hydration process caused by the dilution effect [44]. The damages inflicted by $\mathrm{Ca}(\mathrm{OH})_{2}$ upon heating at high temperatures also decreased, indicating the excellent thermal performance of MUHPC.

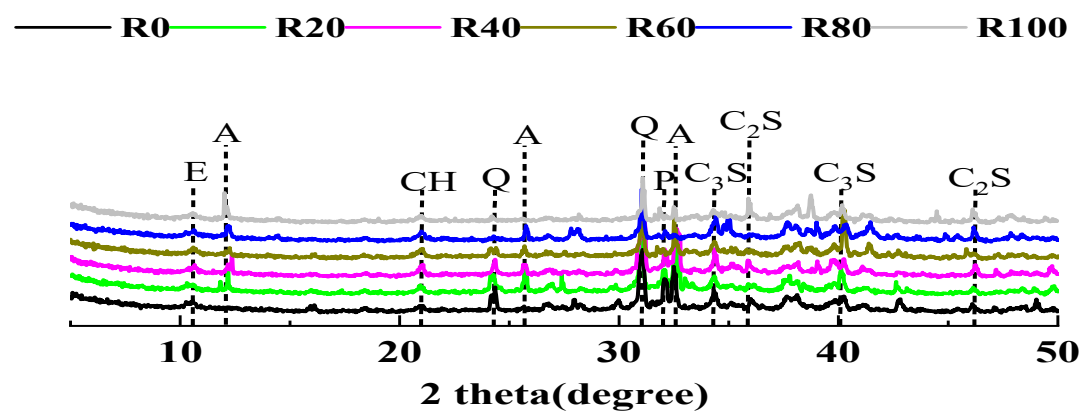

Figure 9. XRD patterns of MUHPC (A: albite; $\mathrm{CH}$ : portlandite; $\mathrm{C}_{2} \mathrm{~S}$ : dicalcium silicate; $\mathrm{C}_{3} \mathrm{~S}$ : tricalcium silicate; E: ettringite; P: potash feldspar; Q: quartz.). 


\subsection{Micromorphology}

A typical SEM image of sample R100 aged for 28 days is presented in Figure 10. The microstructure of UHPC with magnetite fine aggregate looks very dense. No obvious interfacial transition zone was observed between magnetite aggregate and cement paste, and the addition of magnetite fine aggregate exerted no adverse effects on the microstructures in concrete, which may be the reason why UHPC with magnetite can retain its good mechanical properties.
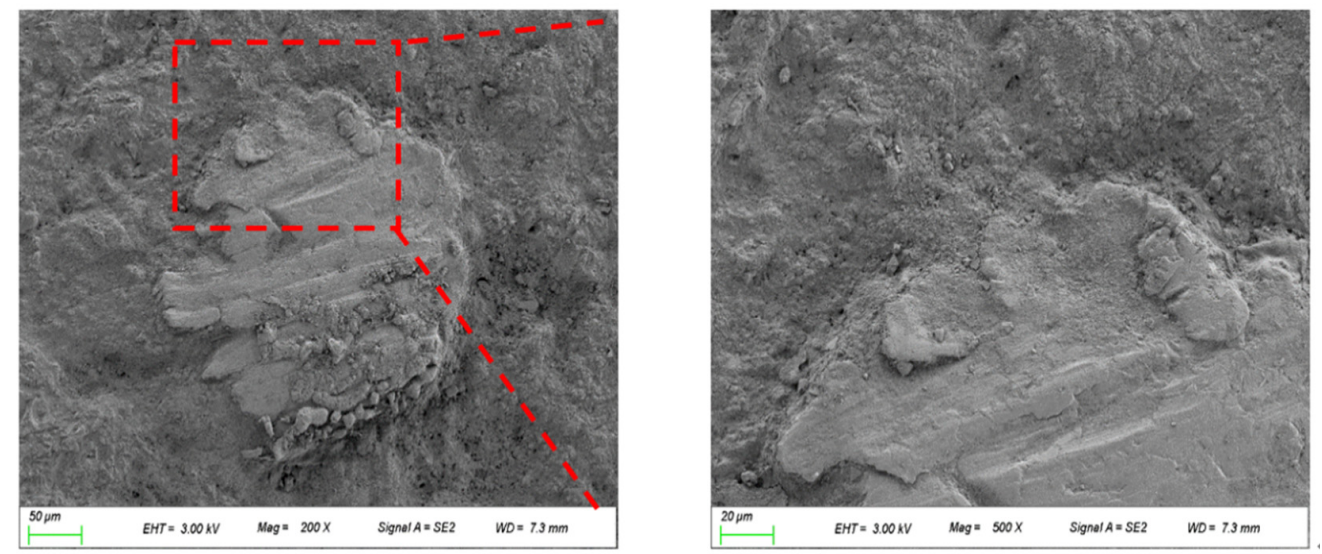

Figure 10. A typical SEM image of sample R100.

\subsection{Micropore Structures}

Generally, porosity and pore size distribution are the two key factors affecting the compressive strength and radiation shielding performance of concrete $[55,60]$. Based on the MIP experimental results, the micropore structure information of different MUHPC samples are listed in Table 5. Some discreteness in the data may be observed, but the total porosity and the average pore diameter of MUHPC decreased after the addition of magnetite fine aggregate. For example, with increased content of magnetite in MUHPC from $0 \%$ to $20 \%, 40 \%, 60 \%, 80 \%$, and $100 \%$, the total porosity decreased from $9.41 \%$ to $6.70 \%, 7.84 \%, 8.50 \%, 8.03 \%$, and $6.15 \%$, with an average reduction of $1.97 \%$. This may be due to the incorporation of magnetite particles that improved the grading curve of MUHPC particles, and the magnetite particles provided roughness and were closely connected with concrete matrix.

Table 5. MIP results of MUHPC samples.

\begin{tabular}{ccccc}
\hline Samples & Porosity (\%) & $\begin{array}{c}\text { Average Pore } \\
\text { Diameter }(\mathbf{n m})\end{array}$ & $\begin{array}{c}\text { Critical Pore } \\
\text { Radius (nm) }\end{array}$ & $\begin{array}{c}\text { Median Pore } \\
\text { Diameter (nm) }\end{array}$ \\
\hline R0 & 9.41 & 14.3 & 3.29 & 5.03 \\
R20 & 6.70 & 7.62 & 4.52 & 5.04 \\
R40 & 7.84 & 9.91 & 3.29 & 4.82 \\
R60 & 8.50 & 10.99 & 3.29 & 4.98 \\
R80 & 8.03 & 12.31 & 7.23 & 6.48 \\
R100 & 6.15 & 9.03 & 6.02 & 5.63 \\
\hline
\end{tabular}

To further study the influence of magnetite content on the micropore structure of MUHPC, the measured pore sizes were divided into harmless pores $(<20 \mathrm{~nm})$, mesopore $(20-50 \mathrm{~nm})$, middle capillary pores $(50-200 \mathrm{~nm})$, and macrocapillary pores $(>200 \mathrm{~nm})[63,64]$. The histogram of pore size distribution is shown in Figure 11. The proportion of harmless pores in the reference group (R0) was $45 \%$. With the addition of magnetite, the proportions of harmless pores in samples R20, R40, R60, R80, and R100 increased to 79\%, 57\%, 63\%, $59 \%$, and $70 \%$, respectively. Although there was some discreteness, the proportions of harmless pores significantly increased, whereas the proportions of large capillary pores that 
primarily affected the performance of MUHPC decreased by $55 \%, 2.5 \%, 10 \%, 12.5 \%$, and $32.5 \%$, respectively. As an inert fine aggregate, magnetite fine aggregate does not change the type of cement hydration products, but improves the micropore structures of MUHPC, making it denser and finer through irregular shapes and filling effects, thus contributing to its mechanical and radiation shielding performance.

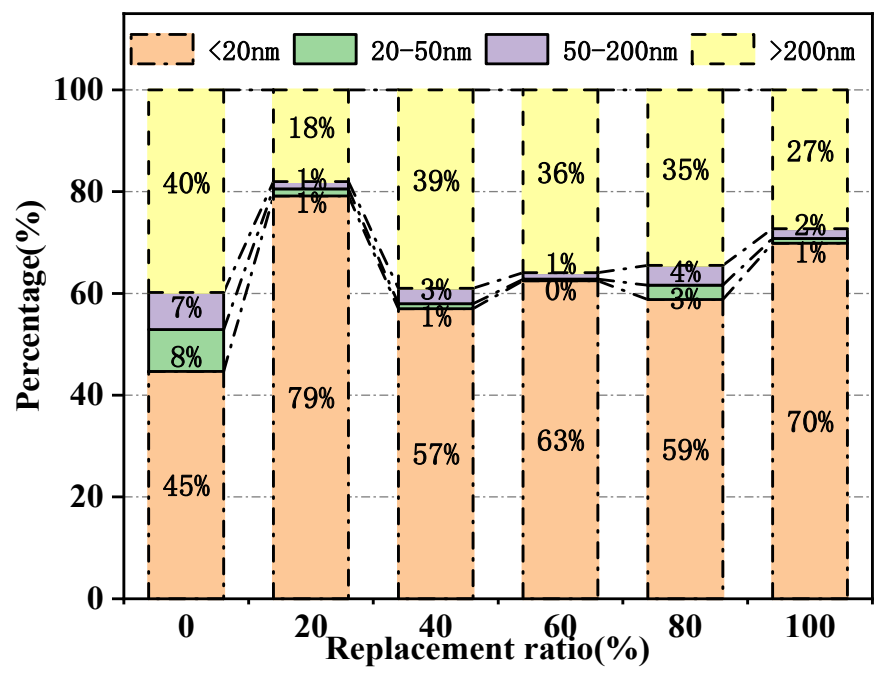

Figure 11. Pore size distribution histogram of MUHPC.

The typical MIP curves of R100 after high-temperature exposure are shown in Figure 12. The total pore volume remarkably increased after heat treatment at $200{ }^{\circ} \mathrm{C}$ or $400{ }^{\circ} \mathrm{C}$, and a higher temperature exposure corresponded with a higher porosity of concrete. Notably, the increase in concrete porosity was primarily caused by the micropores within $10 \mathrm{~nm}$ after exposure to $200{ }^{\circ} \mathrm{C}$, which may explain why the compressive strength of MUHPC after heating at $200{ }^{\circ} \mathrm{C}$ was not seriously affected. When exposed to $400{ }^{\circ} \mathrm{C}$, the micropore structure of MUHPC severely deteriorated, i.e., the pore sizes enlarged and the harmful pores obviously increased. These phenomena were also the main reasons for the deterioration in MUHPC strength and radiation shielding performance after hightemperature exposure.

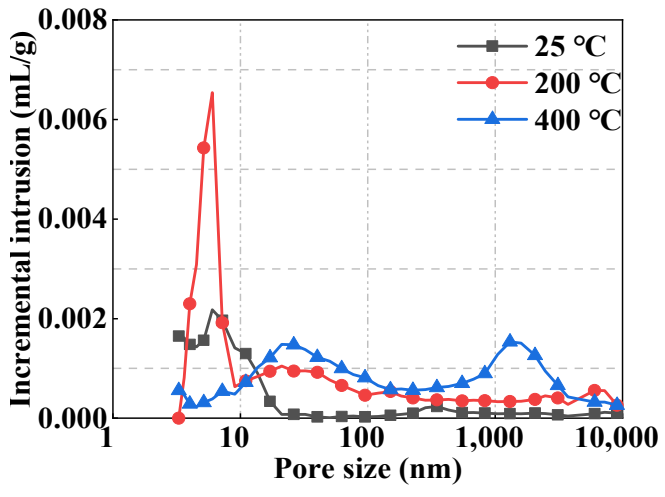

(a)

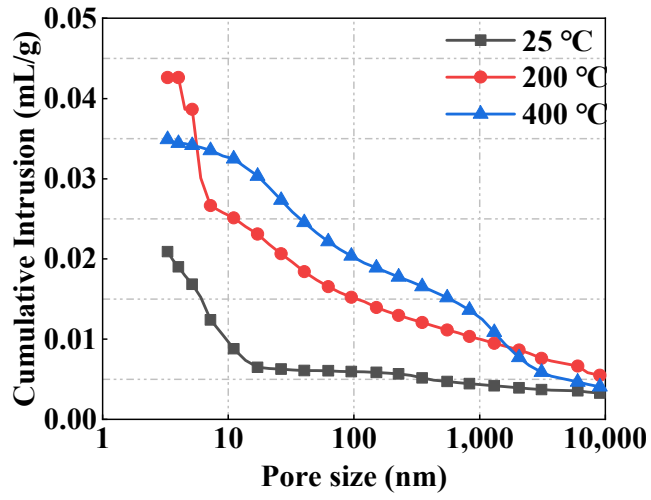

(b)

Figure 12. Micropore structures of R100 after high-temperature exposure. (a) Differential pore size distribution. (b) Cumulative pore size distribution.

The compressive strengths of MUHPC developed herein ranged within 149-156 MPa, which is much higher than that of most conventional radiation-proof concretes, whose strengths range within 25-58 $\mathrm{MPa}$ ) [65-67]. In terms of radiation safety performance, the $\mu$ values of MUHPC ranged within $0.1538-0.2019 \mathrm{~cm}^{-1}$, whereas the $\mu$ values in compara- 
tive literature ranged within 0.1-0.1916 $\mathrm{cm}^{-1}$ [10,66-68]. Thus, MUHPC exhibits excellent radiation shielding performance. MUHPC also has good work performance, high dynamic strength, and strong thermal performance. Overall, the developed MUHPC has excellent comprehensive properties and can thus be used to construct high-power nuclear facilities.

\section{Conclusions}

Based on the experiments, some conclusions have been drawn:

(1) A novel antiradiation MUHPC was developed using magnetite fine aggregate to partially replace river sands. When $100 \%$ magnetite fine aggregate replaced river sand, the prepared MUHPC still had fairly good fluidity $(>200 \mathrm{~mm})$, and the static and dynamic compressive strengths were 149 and $218 \mathrm{MPa}$. In particular, when the heating temperature reached $200{ }^{\circ} \mathrm{C}$, the compressive strength of the MUHPC was $171 \mathrm{MPa}$, which was $13.25 \%$ higher than that of the control. Thus, the MUHPC has high density, good work performance, satisfactory static and dynamic compressive strengths, and high thermal performance.

(2) The addition of magnetite fine aggregate can effectively enhance the radiation shielding performance of UHPC, and a higher replacement ratio of magnetite fine aggregate corresponds with higher radiation resistance. Compared with that of ordinary concrete, the radiation resistance of MUHPC improved by $19.4 \%, 29.4 \%, 31.4 \%, 48.8 \%$, and $56.8 \%$, corresponding with $0 \%$ to $20 \%, 40 \%, 60 \%, 80 \%$, and $100 \%$ magnetite replacement ratios. The developed MUHPC not only has ultra-high mechanical properties and durability, but also the radiation shielding performance is greatly improved compared with ordinary concrete.

(3) As an inert fine aggregate, magnetite fine aggregate does not change the type of cement hydration products but improves the micropore structures of MUHPC, making it denser and finer through irregular shapes and filling effects. These phenomena contribute to the enhancement in mechanical properties and radiation shielding performance of MUHPC. Although high temperature will worsen the pore structure of MUHPC, the developed MUHPC still has high compressive strength (149 $\mathrm{MPa})$ and radiation resistance $\left(0.1908 \mathrm{~cm}^{-1}\right)$ when the heating temperature is lower than $400{ }^{\circ} \mathrm{C}$.

(4) Compared with ordinary magnetite concrete with good radiation shielding performance and ordinary UHPC with low radiation shielding performance, a kind of MUHPC with excellent radiation shielding performance is formulated by combining the two aspects. It provides a new idea for the development of radiation shielding materials in the future.

Author Contributions: Conceptualization, J.H.; methodology, Y.L.; software, Z.X.; validation, R.Y.; formal analysis, Z.X.; data curation, J.G.; writing-original draft preparation, Z.X.; writing-review and editing, G.L.; funding acquisition, Y.L. All authors have read and agreed to the published version of the manuscript.

Funding: The authors are grateful for financial support from the National Natural Science Foundation of China (grant number 51779096, 51979169) and Open Fund of China Academy of Water Resources and Hydropower (IWHR-SKL-KF202017).

Institutional Review Board Statement: Not applicable.

Informed Consent Statement: Not applicable.

Data Availability Statement: Data are contained with the article.

Acknowledgments: The authors are grateful for the device support from the Advanced Analysis and Computation Center of China University of Mining and Technology.

Conflicts of Interest: We declare that we do not have any commercial or associative interest that represents a conflict of interest in connection with the work submitted.

\section{References}

1. Akkurt, I.; Akyildirim, H.; Mavi, B.; Kilincarslan, S.; Basyigit, C. Gamma-ray shielding properties of concrete including barite at different energies. Prog. Nucl. Energy 2010, 52, 620-623. [CrossRef]

2. Azeez, M.O.; Ahmad, S.; Al-Dulaijan, S.U.; Maslehuddin, M.; Naqvi, A.A. Radiation shielding performance of heavy-weight concrete mixtures. Constr. Build. Mater. 2019, 224, 284-291. [CrossRef] 
3. Singh, C.; Singh, T.; Kumar, A.; Mudahar, G.S. Energy and chemical composition dependence of mass attenuation coefficients of building materials. Ann. Nucl. Energy 2004, 31, 1199-1205. [CrossRef]

4. Yan, J.; Lin, Y.; Wang, Z.; Fang, T.; Ma, J. Failure mechanism of a prestressed concrete containment vessel in nuclear power plant subjected to accident internal pressure. Ann. Nucl. Energy 2019, 133, 610-622. [CrossRef]

5. $\quad$ Lawrence, D.J.; Feldman, W.C.; Gold, R.E.; Goldsten, J.O.; McNutt, R.L. The neutron, gamma-ray, X-ray spectrometer (NGXS): A compact instrument for making combined measurements of neutrons, gamma-rays, and X-rays. Acta Astronaut. 2014, 93, 524-529. [CrossRef]

6. Zayed, A.M.; Masoud, M.A.; Rashad, A.M.; El-Khayatt, A.M.; Sakr, K.; Kansouh, W.A.; Shahien, M.G. Influence of heavyweight aggregates on the physico-mechanical and radiation attenuation properties of serpentine-based concrete. Constr. Build. Mater. 2020, 260, 120473. [CrossRef]

7. Zervides, C.; Sassis, L.; Kefala-Karli, P.; Christou, V.; Derlagen, A.; Papapetrou, P.; Heraclides, A. Assessing radiation protection knowledge in diagnostic radiography in the Republic of Cyprus. A questionnaire survey. Radiography 2020, 26, e88-e93. [CrossRef]

8. Li, C.; Zhang, C.; Chen, Y.; Zuo, J.; Chen, J. The study on safety goals and public acceptance of nuclear power. Energy Procedia 2013, 39, 415-422.

9. Jin, T.; Kim, J. What is better for mitigating carbon emissions-Renewable energy or nuclear energy? A panel data analysis. Renew. Sustain. Energy Rev. 2018, 91, 464-471. [CrossRef]

10. Mahmood, N.; Danish; Wang, Z.; Zhang, B. The role of nuclear energy in the correction of environmental pollution: Evidence from Pakistan. Nucl. Eng. Technol. 2020, 52, 1327-1333. [CrossRef]

11. Mergener, M.; Rhoden, C.R.; Amantéa, S.L. Nuclear abnormalities in cells from nasal epithelium: A promising assay to evaluate DNA damage related to air pollution in infants. J. Pediatr. 2014, 90, 632-636. [CrossRef] [PubMed]

12. Portugal-Pereira, J.; Ferreira, P.; Cunha, J.; Szklo, A.; Schaeffer, R.; Araújo, M. Better late than never, but never late is better: Risk assessment of nuclear power construction projects. Energy Policy 2018, 120, 158-166. [CrossRef]

13. Suwanmaneechot, P.; Bongkarn, T.; Joyklad, P.; Julphunthong, P. Experimental and numerical evaluation of gamma-ray attenuation characteristics of concrete containing high-density materials. Constr. Build. Mater. 2021, 294, 123614. [CrossRef]

14. Sharifi, S.; Bagheri, R.; Shirmardi, S.P. Comparison of shielding properties for ordinary, barite, serpentine and steel-magnetite concretes using MCNP-4C code and available experimental results. Ann. Nucl. Energy 2013, 53, 529-534. [CrossRef]

15. Akkurt, I.; Basyigit, C.; Kilincarslan, S.; Mavi, B. The shielding of $\gamma$-rays by concretes produced with barite. Prog. Nucl. Energy 2005, 46, 1-11. [CrossRef]

16. Al-Tersawy, S.H.; El-Sadany, R.A.; Sallam, H.E.M. Experimental gamma-ray attenuation and theoretical optimization of barite concrete mixtures with nanomaterials against neutrons and gamma rays. Constr. Build. Mater. 2021, 289, 123190. [CrossRef]

17. Aygün, B.; Şakar, E.; Agar, O.; Sayyed, M.I.; Karabulut, A.; Singh, V.P. Development of new heavy concretes containing chrome-ore for nuclear radiation shielding applications. Prog. Nucl. Energy 2021, 133, 103645. [CrossRef]

18. Horszczaruk, E.; Sikora, P.; Zaporowski, P. Mechanical properties of shielding concrete with magnetite aggregate subjected to high temperature. Procedia Eng. 2015, 108, 39-46. [CrossRef]

19. Kim, I.S.; Choi, S.Y.; Yang, E.I. Evaluation of durability of concrete substituted heavyweight waste glass as fine aggregate. Constr Build. Mater. 2018, 184, 269-277. [CrossRef]

20. Martínez-Barrera, G.; Ureña-Nuñez, F.; Gencel, O.; Brostow, W. Mechanical properties of polypropylene-fiber reinforced concrete after gamma irradiation. Compos. Part A Appl. Sci. Manuf. 2011, 42, 567-572. [CrossRef]

21. Tufekci, M.M.; Gokce, A. Development of heavyweight high performance fiber reinforced cementitious composites (HPFRCC)Part I: Mechanical properties. Constr. Build. Mater. 2017, 148, 559-570. [CrossRef]

22. AbuAlRoos, N.J.; Amin, N.A.B.; Zainon, R. Conventional and new lead-free radiation shielding materials for radiation protection in nuclear medicine: A review. Radiat. Phys. Chem. 2019, 165, 108439. [CrossRef]

23. Perry, M.; Yan, Z.; Sun, Z.; Zhang, L.; Niewczas, P.; Johnston, M. High stress monitoring of prestressing tendons in nuclear concrete vessels using fibre-optic sensors. Nucl. Eng. Des. 2014, 268, 35-40. [CrossRef]

24. Yılmaz, E.; Baltas, H.E.; Kırıs, İ.; Ustabas, U.; Cevik, A.M. El-Khayatt, Gamma ray and neutron shielding properties of some concrete materials. Ann. Nucl. Energy 2011, 38, 2204-2212. [CrossRef]

25. Liu, J.; Tian, Q.; Wang, Y.; Li, H.; Xu, W. Evaluation Method and Mitigation Strategies for Shrinkage Cracking of Modern Concrete. Engineering 2021, 7, 348-357. [CrossRef]

26. Zhao, H.; Jiang, K.; Yang, R.; Tang, Y.; Liu, J. Experimental and theoretical analysis on coupled effect of hydration, temperature and humidity in early-age cement-based materials. Int. J. Heat Mass Transf. 2020, 146, 118784. [CrossRef]

27. Ouda, A.S.; Abdel-Gawwad, H.A. The effect of replacing sand by iron slag on physical, mechanical and radiological properties of cement mortar. HBRC J. 2017, 13, 255-261. [CrossRef]

28. Çullu, M.; Bakırhan, E. Investigation of radiation absorption coefficients of lead-zinc mine waste rock mixed heavy concrete at 662-1460 keV energy range. Constr. Build. Mater. 2018, 173, 17-27. [CrossRef]

29. Saidani, K.; Ajam, L.; Ouezdou, M.B. Barite powder as sand substitution in concrete: Effect on some mechanical properties. Constr. Build. Mater. 2015, 95, 287-295. [CrossRef]

30. González-Ortega, M.A.; Cavalaro, S.H.P.; Aguado, A. Influence of barite aggregate friability on mixing process and mechanical properties of concrete. Constr. Build. Mater. 2015, 74, 169-175. [CrossRef] 
31. Yang, J.; Wu, H.; Guo, L.; Li, Y.; Li, X.; Wang, S.; Hao, T.; Ji, W. Validation of NECP-Bamboo with BEAVRS and AP1000 measurements. Nucl. Eng. Des. 2021, 376, 111110. [CrossRef]

32. Hou, D.; Wu, D.; Wang, X.; Gao, S.; Yu, R.; Li, M.; Wang, P.; Wang, Y. Sustainable use of red mud in ultra-high performance concrete (UHPC): Design and performance evaluation. Cem. Concr. Compos. 2021, 115, 103862. [CrossRef]

33. Yu, R.; Spiesz, P.; Brouwers, H.J.H. Development of an eco-friendly Ultra-High Performance Concrete (UHPC) with efficient cement and mineral admixtures uses. Cem. Concr. Compos. 2015, 55, 383-394. [CrossRef]

34. Zhang, P.; Wan, J.; Wang, K.; Li, Q. Influence of nano-SiO ${ }_{2}$ on properties of fresh and hardened high performance concrete: A state-of-the-art review. Constr. Build. Mater. 2017, 148, 648-658. [CrossRef]

35. Chen, H.; Yu, Y.; Tang, C. Mechanical properties of ultra-high performance concrete before and after exposure to high temperatures. Materials 2020, 3, 770. [CrossRef]

36. Li, Y.; Zeng, X.; Zhou, J.; Shi, Y.; Umar, H.A.; Long, G.; Xie, Y. Development of an eco-friendly ultra-high performance concrete based on waste basalt powder for Sichuan-Tibet Railway. J. Clean. Prod. 2021, 312, 127775. [CrossRef]

37. Zhang, Z.; Xu, X. Static and fatigue behavior of rubber-sleeved stud shear connectors as part of field-cast ultra-high performance concrete connections. Materials 2020, 10, 2269. [CrossRef]

38. Zhang, D.; Tan, K. Effect of various polymer fibers on spalling mitigation of ultra-high performance concrete at high temperature Cem. Concr. Compos. 2020, 114, 103815. [CrossRef]

39. Arora, A.; Yao, Y.; Mobasher, B.; Neithalath, N. Fundamental insights into the compressive and flexural response of binder- and aggregate-optimized ultra-high performance concrete (UHPC). Cem. Concr. Compos. 2019, 98, 1-13. [CrossRef]

40. Bajaber, M.A.; Hakeem, I.Y. UHPC evolution, development, and utilization in construction: A review. J. Mater. Res. Technol. 2021, 10, 1058-1074. [CrossRef]

41. Chen, S.; Huang, Y.; Gu, P.; Wang, J.-Y. Experimental study on fatigue performance of UHPC-orthotropic steel composite deck. Thin-Walled Struct. 2019, 142, 1-18. [CrossRef]

42. Huang, H.; Gao, X.; Teng, L. Fiber alignment and its effect on mechanical properties of UHPC: An overview. Constr. Build. Mater 2021, 296, 123741. [CrossRef]

43. Oh, T.; You, I.; Banthia, N.; Yoo, D.-Y. Deposition of nanosilica particles on fiber surface for improving interfacial bond and tensile performances of ultra-high-performance fiber-reinforced concrete. Compos. Part B Eng. 2021, 221, 109030. [CrossRef]

44. Wang, X.; Yu, R.; Shui, Z.; Song, Q.; Liu, Z.; Bao, M.; Liu, Z.; Wu, S. Optimized treatment of recycled construction and demolition waste in developing sustainable ultra-high performance concrete. J. Clean. Prod. 2019, 221, 805-816. [CrossRef]

45. Jiao, Y.; Zhang, Y.; Guo, M.; Zhang, L.; Ning, H.; Liu, S. Mechanical and fracture properties of ultra-high performance concrete (UHPC) containing waste glass sand as partial replacement material. J. Clean. Prod. 2020, 277, 123501. [CrossRef]

46. $\mathrm{Wu}, \mathrm{Z}$; $\mathrm{Shi}, \mathrm{C}$; He, W. Comparative study on flexural properties of ultra-high performance concrete with supplementary cementitious materials under different curing regimes. Constr. Build. Mater. 2017, 136, 307-313. [CrossRef]

47. Zhang, H.; Ji, T.; Lin, X. Pullout behavior of steel fibers with different shapes from ultra-high performance concrete (UHPC) prepared with granite powder under different curing conditions. Constr. Build. Mater. 2019, 211, 688-702. [CrossRef]

48. Rashid, R.S.M.; Salem, S.M.; Azreen, N.M.; Voo, Y.L.; Haniza, M.; Shukri, A.A.; Yahya, M.-S. Effect of elevated temperature to radiation shielding of ultra-high performance concrete with silica sand or magnetite. Constr. Build. Mater. 2020, $262,120567$. [CrossRef]

49. Wang, X.; Yu, R.; Shui, Z.; Zhao, Z.; Song, Q.; Yang, B.; Fan, D. Development of a novel cleaner construction product: Ultra-high performance concrete incorporating lead-zinc tailings. J. Clean. Prod. 2018, 196, 172-182. [CrossRef]

50. BS-EN-1015-3; Methods of Test for Mortar for Masonry-Part 3: Determination of Consistence of Fresh Mortar (by Flow Table). BSI Publications: London, UK, 2007.

51. BS-EN-196-1; Methods of Testing Cement-Part 1: Determination of Strength. BSI Publications: London, UK, 2016.

52. Theresa, M.A.; Charles, K.C.; Claus, B.; Benjamin, G.; James, M.; Surendra, P.S.; Eckart, R.B.; Brian, H.G.; John, J.M.; Kay, W.; et al. Ultra-High-Performance Concrete: An Emerging Technology Report; American Concrete Institute: Farmington Hills, MI, USA, 2018; ISBN 978-1-64195-034-3.

53. Wang, W.; Zhang, X.; Mo, Z.; Chouw, N.; Li, Z.; Xu, Z.-D. A comparative study of impact behaviour between natural flax and glass FRP confined concrete composites. Constr. Build. Mater. 2020, 241, 117997. [CrossRef]

54. Li, N.; Jin, Z.Q.; Long, G.; Chen, L.; Fu, Q. Impact resistance of steel fiber-reinforced self-compacting concrete (SCC) at high strain rates. J. Build. Eng. 2021, 38, 102212. [CrossRef]

55. Rashad, A.M.; Zeedan, S.R. A preliminary study of blended pastes of cement and quartz powder under the effect of elevated temperature. Constr. Build. Mater. 2012, 29, 672-681. [CrossRef]

56. Hossain, K.M.A. High strength blended cement concrete incorporating volcanic ash: Performance at high temperatures. Cem. Concr. Compos. 2006, 28, 535-545. [CrossRef]

57. Zhang, P.; Gao, Z.; Wang, J.; Guo, J.; Hu, S.; Ling, Y. Properties of fresh and hardened fly ash/slag based geopolymer concrete: A review. J. Clean. Prod. 2020, 270, 122389. [CrossRef]

58. Georgali, B.; Tsakiridis, P.E. Microstructure of fire-damaged concrete. A case study. Cem. Concr. Compos. 2005, 27, 255-259. [CrossRef]

59. Khan, M.U.; Ahmad, S.; Naqvi, A.A.; Al-Gahtani, H.J. Shielding performance of heavy-weight ultra-high-performance concrete against nuclear radiation. Prog. Nucl. Energy 2020, 130, 103550. [CrossRef] 
60. Sikora, P.; Elrahman, M.A.; Horszczaruk, E.; Brzozowski, P.; Stephan, D. Incorporation of magnetite powder as a cement additive for improving thermal resistance and gamma-ray shielding properties of cement-based composites. Constr. Build. Mater. 2019, 204, 113-121. [CrossRef]

61. Oberer, R.B.; Gunn, C.A.; Chiang, L.G. Small-angle Compton scattering used to determine the depth of a radioactive source in material and to estimate gamma-ray attenuation, Nuclear Instruments and Methods in Physics Research Section A: Accelerators, Spectrometers. Detect. Assoc. Equip. 2013, 722, 65-70. [CrossRef]

62. Wu, C.-R.; Hong, Z.-Q.; Yin, Y.-H.; Kou, S.-C. Mechanical activated waste magnetite tailing as pozzolanic material substitute for cement in the preparation of cement products. Constr. Build. Mater. 2020, 252, 119129. [CrossRef]

63. Li, G.; Zhou, J.; Yue, J.; Gao, X.; Wang, K. Effects of nano-SiO 2 and secondary water curing on the carbonation and chloride resistance of autoclaved concrete. Constr. Build. Mater. 2020, 235, 117465. [CrossRef]

64. Li, G.; Ding, Y.; Gao, T.; Qin, Y.; Lv, Y.; Wang, K. Chloride resistance of concrete containing nanoparticle-modified polymer cementitious coatings. Constr. Build. Mater. 2021, 299, 123736. [CrossRef]

65. Baalamurugan, J.; Kumar, V.G.; Chandrasekaran, S.; Balasundar, S.; Venkatraman, B.; Padmapriya, R.; Raja, V.K.B. Recycling of steel slag aggregates for the development of high density concrete: Alternative \& environment-friendly radiation shielding composite. Compos. Part B Eng. 2021, 216, 108885.

66. El-Sayed, T.A. Performance of heavy weight concrete incorporating recycled rice straw ash as radiation shielding material. Prog. Nucl. Energy 2021, 135, 103693. [CrossRef]

67. Yao, Y.; Zhang, X.; Li, M.; Yang, R.; Jiang, T.; Lv, J. Investigation of gamma ray shielding efficiency and mechanical performances of concrete shields containing bismuth oxide as an environmentally friendly additive. Radiat. Phys. Chem. 2016, 127, 188-193. [CrossRef]

68. Azreen, N.M.; Rashid, R.S.M.; Haniza, M.; Voo, Y.L.; Amran, Y.H.M. Radiation shielding of ultra-high-performance concrete with silica sand, amang and lead glass. Constr. Build. Mater. 2018, 172, 370-377. [CrossRef] 